\title{
Prediction and diagnosis of sickling disorders in neonates
}

\author{
N ADJAYE, ${ }^{*}$ B J BAIN, $\dagger$ AND P STEER $\ddagger$ \\ Departments of *Paediatrics, †Haematology, and $¥$ Obstetrics, St Mary’s Hospital and St Mary’s Hospital \\ Medical School, London
}

SUMmARY A pilot scheme for the prediction and detection of sickle cell disease in neonates was set up and the results from its first three years of operation analysed. A total of 153 women booking at the antenatal clinic were found to have haemoglobin $\mathrm{S}$. The protocol required that all partners of the women so identified be screened for abnormal haemoglobins and $\beta$ thalassaemia trait, and that the babies of these women should have cord blood electrophoresis performed. In fact this was only achieved in 75 partners $(49 \%)$ and 91 of 145 infants $(63 \%)$. Of 10 babies born with sickle cell disease during the study period, nine had mothers known to have haemoglobin $\mathrm{S}$ or C, but only four of these mothers' partners had been tested before delivery of the child.

This pilot study highlights the problems in establishing effective antenatal screening programmes, especially in ethnic minority groups. The results show that detailed staff training, careful organisation of administrative arrangements, and education of 'at risk' groups should all be undertaken before the launching of major screening initiatives.

The mortality from sickle cell disease is high in the first two years of life. ${ }^{12}$ It has been suggested that mortality is lowered by early detection as this ensures that medical and child health staff are alerted to potential problems and it permits the education of parents and the administration of prophylactic penicillin to the infant. ${ }^{3-5}$

Paddington and North Kensington district is a deprived multiethnic inner city health district where $10 \%$ of births are to mothers of African or Caribbean origin. In 1983 a multidisciplinary team drawn from the departments of obstetrics, paediatrics, child health, and haematology was convened to study the problems associated with the establishment of a screening programme for the prediction and detection of sickling disorders in the neonate. A protocol was drawn up so that all women were managed according to the same guidelines. This paper presents the results of the first three years of the study (1 July 1983 to 30 June 1986). As is conventional, we have used the term 'sickle cell anaemia' to indicate homozygosity for the sickle cell gene and 'sickle cell disease' to include also other sickling disorders such as double heterozygosity for both the sickle cell gene and either $\beta$ thalassaemia trait or haemoglobin C. A programme to predict $\beta$ thalassaemia major in neonates was introduced simultaneously with the sickle cell screening programme. $^{6}$

\section{Patients and methods}

All women booking at district antenatal clinics had their ethnic origin recorded in a designated box on haematology request forms using the following general categories: black, Indian subcontinent, oriental, Mediterranean, caucasian (other than Indian subcontinent and Mediterranean), and other. Antenatal clinic staff requested a full blood count, blood film examination, and sickle solubility test at booking on all women classified as black. If the antenatal clinic staff identified a woman as black but failed to request a sickle screen the protocol required that the test be initiated by laboratory staff. If the sickle solubility test was positive, haemoglobin electrophoresis was performed. In addition, black women with microcytic red cells (mean corpuscular volume less than $83 \mathrm{fl}$ ) had haemoglobin electrophoresis and a haemoglobin $\mathrm{A}_{2}$ estimation performed as part of the programme for prediction of $\beta$ thalassaemia major. ${ }^{6}$

In the early part of the study it was not considered feasible to screen all black women for the presence of haemoglobin $\mathrm{C}$, but a small number of women 
who were sickle negative had haemoglobin electrophoresis performed because target cells were noted in the blood film. In the latter part of the study haemoglobin electrophoresis was performed on the blood of all black women irrespective of the results of the sickle solubility test. Because no extra staff or other resources were available to establish a formal screening programme, a decision was made to restrict screening for haemoglobin S to black women rather than also to attempt systematic screening of other ethnic groups where a lower but appreciable incidence of the sickle cell gene occurs. The diagnosis of sickle cell trait was therefore made only occasionally in non-black women. It was because of the same constraints that we did not initially routinely screen for haemoglobin $\mathrm{C}$.

Women presenting before 24 weeks of gestation in whom a diagnosis of sickle cell trait, haemoglobin $\mathrm{C}$ trait, or $\beta$ thalassaemia trait was made were contacted by telephone, in the first instance by the antenatal clinic sister who gave a brief explanation of the test result and invited the woman to bring her partner to the clinic for testing. The woman and her partner were then given a further explanation of the test result by a doctor of at least registrar status. Tests performed on the blood of partners were full blood count, sickle solubility test, haemoglobin electrophoresis (irrespective of the results of the sickle solubility test) and, if the partner's red cells were microcytic, haemoglobin $\mathbf{A}_{2}$ estimation. When tests in the partner indicated a risk of sickle cell disease in the fetus and the patient was not already seeing the consultant, referral was arranged, except in those instances when the patient stated that she did not have any interest in antenatal diagnosis. The patient was advised as to the possible outcome of pregnancy, and when sufficiently early in pregnancy, the options of antenatal diagnosis and termination of pregnancy were fully discussed. Referral to a Sickle Cell Centre was offered when women wished to have the opportunity for further explanation and discussion. Patients who presented later than 24 weeks of gestation were in general not recalled early but an explanation was given and testing of the partner was offered at the next clinic attendance.

The protocol required that cord blood samples be obtained from all black babies whose mothers were known to have sickle cell trait, haemoglobin $\mathrm{C}$ trait, or $\beta$ thalassaemia trait. The labour ward was alerted to the need for such tests by (a) a statement of the sickle status on the front of the obstetric notes and (b) either a stamp or a written request on the labour ward page. Cord blood samples were also required on black babies whose mothers presented for the first time already in labour, or whose haemoglobin status was otherwise unknown. Cord blood samples were anticoagulated with edetic acid and were used for a full blood count and haemoglobin electrophoresis. When a cord blood sample showed a baby to have sickle cell disease the baby and the mother were recalled to a joint haematology and paediatric clinic. When cord blood showed haemoglobin F only or haemoglobins F, S, and A with haemoglobin S apparently in excess of haemoglobin A (possible haemoglobin $S / \beta^{+}$thalassaemia) the mother and the baby were recalled at six weeks for further testing. Recalling of mothers and babies was performed by a lecturer in community paediatrics.

In order to check as far as possible whether all cases of sickle cell disease in neonates had been predicted by the programme, we examined the records of all cord blood electrophoresis performed for any reason and all electrophoresis on infants performed within the district during the period of the study and for seven months thereafter.

Sickle solubility tests were performed using the Mercia Diagnostics S-test kit. Haemoglobin electrophoresis was performed on cellulose acetate at $\mathrm{pH}$ $8 \cdot 2$ to $8 \cdot 6$. When necessary (to distinguish haemoglobins $D$ and $G$ from $S$ and to distinguish between haemoglobins $C$ and $E$ ) electrophoresis was also performed on citrate agar at $\mathrm{pH} 6.0$ to 6.2 .

At the beginning of the study period information sheets for both staff and pregnant women were drawn up and distributed to the antenatal clinics and to all senior medical and midwifery staff. Appropriate seminars and study days were arranged.

\section{Results}

During the three years surveyed, 153 women were identified as having haemoglobin S; 149 had sickle trait, two were double heterozygotes for S and C, one had sickle cell anaemia, and one was heterozygous for both haemoglobin $S$ and the $\alpha$ chain variant haemoglobin G Philadelphia. A total of 148 women who were sickle positive were black, three were Indian, one Moroccan, and one Libyan. Of the five non-black women, four were investigated because they were microcytic and one because haemoglobin electrophoresis was specifically requested by obstetric staff.

In 57 cases $(37 \%)$ the woman's partner was investigated by us and in a further 18 cases $(12 \%)$ the woman stated that her partner had already been investigated and was known to be sickle negative; partners were therefore investigated in 75 instances (49\%). When partners were not investigated explanations were sometimes recorded in the notes as follows: 12 women miscarried or transferred to another clinic; in 14 instances testing was offered but was not desired; in seven cases the partner was not 
tested because he was caucasian; in five instances the partner was not in the United Kingdom and in six cases he was otherwise unavailable. In 34 cases $(22 \%)$ no reason for not testing the partner was recorded in the notes; this group included many women who presented late in pregnancy or already in labour.

A total of 141 women gave birth to a total of 145 live infants. Of the 145 infants, cord blood samples were obtained in 91 instances $(63 \%)$. The results of electrophoresis of these cord blood samples are shown in the table.

A definitive diagnosis of sickle cell disease was made in five cases $(5.5 \%$ of cord bloods screened); one case was of sickle cell/haemoglobin $\mathrm{C}$ disease, and four were either sickle cell anaemia or double heterozygosity for haemoglobin $S$ and $\beta^{\circ}$ thalassaemia. In 12 instances $(13.3 \%)$ further follow up electrophoresis was required because only haemoglobin $F$ was present at birth or other bands were too faint to allow a confident diagnosis. Such follow up proved difficult: in five instances the infant was retested by us or elsewhere but in seven cases efforts to have the baby brought to the clinic for repeat testing were unsuccessful.

Investigation of the results of haemoglobin electrophoresis performed on cord bloods and on the blood of infants during and after the period of this study disclosed a total of 10 instances of sickle cell disease in the infants of mothers who became pregnant during the study, three of the 10 being double heterozygotes for haemoglobin $\mathrm{S}$ and haemoglobin C. Because of the method of ascertainment 10 cases may well be an underestimate. Mothers of six of the 10 cases were detected by the screening programme, five being the babies of mothers with haemoglobin $S$; the sixth was the baby of a mother whose antenatal screening had shown her to have haemoglobin $\mathrm{C}$ trait. Another three babies were born in hospital but their mothers had never attended the antenatal clinic; all antenatal care including sickle screening had been provided by their general practitioner. In the one remaining instance the mother had attended the hospital antenatal clinic but had not been tested for haemoglobin S; in this patient both the antenatal clinic staff and the laboratory staff failed to initiate the test and no further action was taken by antenatal staff on subsequent clinic attendances. Of the nine mothers who had been tested antenatally one stated that she was not aware of the test result. Only four fathers had been tested before the delivery of the child; in three cases the test had been offered and declined but in three cases there was no record that the test had been offered. In addition one mother said that she had been unaware of the test result in her partner. One couple had been offered antenatal diagnosis and had accepted but had decided to continue with the pregnancy after the diagnosis of sickle cell anaemia as the mother had felt fetal movements and this made termination of pregnancy unacceptable to her. ${ }^{7}$

The extension of the use of haemoglobin electrophoresis to all black women, irrespective of the results of the sickle solubility test, did not disclose any unexpected cases of sickle cell trait, although the rate of diagnosis of haemoglobin $\mathrm{C}$ trait increased considerably.

\section{Discussion}

Many of the problems involved in predicting the possibility of neonatal sickle cell disease and in offering antenatal diagnosis are highlighted in this study. Many women in the groups at risk present late in pregnancy. Sometimes ethnic origin is difficult to categorise, and not all women are aware of

Table Results of cord blood haemoglobin electrophoresis $(n=91)$

\begin{tabular}{|c|c|c|c|}
\hline $\begin{array}{l}\text { Haemoglobins } \\
\text { detected }\end{array}$ & Interpretation & $\begin{array}{l}\text { No of } \\
\text { infants }\end{array}$ & Follow up \\
\hline $\mathbf{F}+\mathbf{A}$ & Normal & 43 & - \\
\hline $\mathbf{F}+\mathbf{A}+\mathbf{S}$ & Sickle cell trait & 28 & - \\
\hline $\mathbf{F}+\mathbf{S}$ & $\begin{array}{l}\text { Probable sickle cell } \\
\text { disease (sickle cell anaemia or } S / \beta^{\circ} \\
\text { thalassaemia) }\end{array}$ & 6 & $\begin{array}{l}4 \text { sickle cell anaemia or } \\
\mathrm{S} / \beta^{\circ} \text { thalassaemia, } \\
1 \text { sickle trait, } 1 \text { failed } \\
\text { follow up }\end{array}$ \\
\hline $\mathbf{F}+\mathbf{S}+\mathbf{C}$ & $\begin{array}{l}\text { Heterozygosity for haemoglobins } \mathrm{S} \text { and } \mathrm{C} \\
\text { (sickle cell/haemoglobin } \mathrm{C} \text { disease) }\end{array}$ & 1 & $\begin{array}{l}1 \text { sickle cell/haemoglobin } \mathrm{C} \\
\text { disease }\end{array}$ \\
\hline $\begin{array}{l}\text { F only or } \mathrm{F}+\text { indistinct } \\
\text { bands }\end{array}$ & Follow up required for interpretation & 12 & $\begin{array}{l}4 \text { sickle trait, } 1 \text { referred } \\
\text { elsewhere, } 7 \text { not traced }\end{array}$ \\
\hline Other & $\begin{array}{l}\text { Haemoglobin C trait or other abnormal } \\
\text { haemoglobins }\end{array}$ & 1 & 1 Haemoglobin $\mathrm{C}$ trait \\
\hline
\end{tabular}


their racial ancestry. Some antenatal clinic staff are reluctant to categorise women by race, fearing that their motives may be misunderstood, and some simply forget to do it. Blood samples sometimes get lost and some results never reach the clinic or arrive after a long delay. The importance of a positive result may not be appreciated, particularly by staff new to the area, or staff may forget to act upon it. Some women do not wish to have their partners tested, and partners are sometimes unwilling to be tested or unavailable. In our series fewer than half the partners were investigated. Counselling about antenatal diagnosis and possible termination of pregnancy is also a difficult area. The severity of sickle cell disease is unpredictable and many medical and nursing staff have ambivalent feelings as to whether or not it is justified to offer termination of pregnancy. Although most feel that parents have a right to know that they may produce a child with a serious disorder and that termination of affected pregnancies is available, they may unwittingly communicate their ambivalence to the parents. In our experience the number of parents who choose to attend for more detailed counselling varies with the enthusiasm of the medical and nursing staff. We think it is important that professional counselling is available, preferably from those with direct experience of sickle disease, and it often helps if the counsellors are from the same ethnic background (such as, for example, those provided by the Sickle Cell Society).

Some of these problems might be avoided by performing electrophoresis on all antenatal women. As most hospitals will have to conduct screening without any increase in funding, however, such a policy is not likely to be affordable; it certainly was not in our case. We did screen for the $\beta$ thalassaemia trait which may interact with haemoglobin $S$ from the partner; the results of this programme are reported elsewhere. ${ }^{6}$ We recognised that haemoglobin $\mathrm{C}$ might escape detection but as sickle cell/ haemoglobin $\mathrm{C}$ disease is less severe than sickle cell anaemia we felt this was acceptable at the time; we have now expanded our screening to detect haemoglobin $\mathrm{C}$ also.

Our study has also showed some of the problems that occur in screening neonates for sickle cell disease. It has been suggested that in certain communities all neonates should be screened. ${ }^{35}$ One such programme in a community in which $3 \%$ of babies were black was abandoned after screening 7691 babies because no significant haemoglobinopathies had been found. ${ }^{8}$ In two other communities with $10 \%{ }^{9}$ and $22 \%{ }^{5}$ of babies being black the cost of each case detected was estimated at $£ 705$ and $£ 118$ respectively (about $£ 885$ and $£ 135$ at current prices). Because of resource constraints we chose to screen only babies of black mothers who had not been tested and of those known to have haemoglobin $S$ or $C$ or $\beta$ thalassaemia trait. A selective programme such as this may mean that some affected babies are not detected.

We succeeded in testing only $63 \%$ of babies whose mothers had haemoglobin S. This was due both to failure to flag the notes appropriately in the antenatal clinic, and to labour ward staff overlooking the request for cord blood testing stamped on the labour ward page. A policy of testing all black babies or all non-caucasian babies would be administratively simpler than highly selective screening and might lead to testing of a higher percentage of 'at risk' babies. It may be that in communities with a high percentage of non-caucasians comprehensive screening programmes will be found to be necessary if early deaths in infants with sickle cell disease are to be prevented. In our region plans are underway to perform electrophoresis on all samples of blood taken by heel prick on the sixth day of life for Guthrie testing. Careful monitoring of the cost and efficacy will be necessary to ensure that the approach is justified; such monitoring should also be performed in any hospital setting up an antenatal screening programme.

Even when testing of cord blood or of a sample from a neonate shows an abnormality, problems exist in adequate follow up. We were unable to carry out further necessary testing in eight instances. This was consequent on mothers not being traceable or not responding to repeated requests to bring the baby to the clinic. Similar problems in ensuring adequate follow up have been noted in the United States. ${ }^{4}$ Adequate follow up of 'at risk' babies requires an effective mechanism of notification from the laboratory to child health workers and requires a team member who can, when necessary, trace mothers and do home visits. Unless such support is available then resources devoted to the diagnosis of sickle cell disease in the neonate may be wasted.

The findings of our study provide useful information on the difficulties that will be encountered by hospitals seeking to establish a diagnostic service. In the light of this pilot study, we feel there are three important areas that should be addressed before any screening service is set up. Firstly, staff must be thoroughly educated. We found a suprising level of ignorance among both medical and midwifery staff, at junior and senior level. Secondly, administrative arrangements for notification of abnormal results, recall, and counselling of patients need to be planned carefully. As a result of our findings during the pilot study, we have now introduced more formalised arrangements for ensuring recall and to 
check that counselling has in fact been provided. Thirdly, a major factor in the surprisingly low uptake of testing was the low level of awareness of the problem in the black population. We consider that educational programmes need to be disseminated much more widely in the 'at risk' populations. This does raise problems of perception in that screening programmes are sometimes seen as racist; however, we anticipate that the offering of screening programmes for cystic fibrosis to the white population, which is expected to occur soon, will help to make this a less contentious issue.

Despite the problems, we consider that antenatal screening for sickle cell disease is an important service that should become generally available.

We would like to thank our colleagues in our respective departments for their help, and in particular Dr R Rivers who kindly read the manuscript.

\section{References}

${ }^{1}$ Rogers DW, Clarke JM, Cupidore L, Ramlal AM, Sparke BR. Early deaths in Jamaican children with sickle cell disease. $\mathrm{Br}$ Med J 1978;i:1515-6.
${ }^{2}$ Warren NS, Carter TP, Humbert JR, Rowley PT. Newborn screening for hemoglobinopathies in New York State: experience of physicians and parents of affected children. $J$ Pediatr 1982;100:373-7.

3 John AB, Ramlal A, Jackson H, Maude GH, Sharma AW, Serjeant GR. Prevention of pneumococcal infection in children with homozygous sickle cell disease. $\mathrm{Br}$ Med J 1984;288: 1567-70.

${ }^{4}$ Grover R, Shahidi S, Fisher B, Goldberg D, Wethers D. Current sickle cell screening for newborns in New York City 1979-1980. Am J Public Health 1983;73:249-52.

5 Henthorn J, Anioniou E, Brozovic M. Screening cord blood for sickle cell haemoglobinopathies in Brent. Br Med J 1984;289: 479-80.

6 Bain BJ. Screening of antenatal patients in a multiethnic community for $\beta$ thalassaemia trait. J Clin Pathol 1988;41:481-5.

${ }^{7}$ Horwell DH, Heaton DE, Old JM. Diagnosis of haemoglobinopathy using cultured chorionic villus cells. Lancet 1985;ii:613-4.

8 Evans DIK, Blair VM. Neonatal screening for haemoglobinopathy. Results in 7691 Manchester newborns. Arch Dis Child 1976;51:127-30.

9 Griffiths KD, Raine DN, Mann JR. Neonatal screening for sickle haemoglobinopathies in Birmingham. Br Med J 1982;284: 933-5.

Correspondence to Dr BJ Bain, Department of Haematology, St Mary's Hospital Medical School, Praed Street, London W2 1PG.

Accepted 15 September 1988 